\title{
Hour Times gram Per Milliliter Per Milligram Per Gram Per Day
}

National Cancer Institute

\section{Source}

National Cancer Institute. Hour Times gram Per Milliliter Per Milligram Per Gram Per Day. NCI Thesaurus. Code C117919.

Hour times gram per milliliter, divided by milligram per gram per day. 